\title{
Foreword 2019
}

Rein Vihalemm (1938-2015) published the story of chemistry becoming a science in 1981, almost twenty years after Thomas S. Kuhn's groundbreaking The Structure of Scientific Revolutions, which changed the overall understanding of the relationship between philosophy and history of science. Deviating from the prevailing tradition of the 1960s when physics unanimously provided philosophers with a model of science, Kuhn paid considerable attention to chemistry and its history. As a result, he introduced two major changes to philosophy of science, emphasising the role of history in understanding scientific ideas and pointing to the diversity of academic disciplines. Vihalemm's views were strongly influenced by Kuhn; however, he did not just adopt Kuhn's approach but developed his historical epistemology further towards a new theoretical account of science. In the 2000s, he started to call it practical realism because of its focus on real scientific practices. An empirically informed, practice-based philosophy of science was the aim that he pursued throughout his entire academic career. A Story of a Science: On the Evolution of Chemistry (in Estonian Ühe teaduse kujunemislugu: keemia arenguteest) is a popular example of such pursuit, aiming at presenting rich historical material in a clearly formulated philosophical framework in an accessible style of writing. Many Estonian scientists have familiarised themselves with the theoretical nature of science by reading this book. We kindly ask the reader to keep in mind that the book was written in the context of Soviet Marxism, the only officially recognised ideology in the Soviet Union. The book bears signs characteristic of the era, such as the mandatory references to the Marxist classics and allusions to the dictated commitment to society's development towards communism. Nevertheless, reasonable ideas such as the significant role of human activities in the understanding of the entities, relations and processes of the real world, salient in Marx's Theses on Feuerbach, have been incorporated in Vihalemm's approach. In his practical realism, he had a broader ambition to overcome the contradictions of traditional representationalism (the Myth of the Given) that had dominated the philosophy of science for a long time. The questions that Vihalemm asks in the book are essential also for the philosophy and history of science today: What is the relationship between the history and the philosophy of science? Why are scientific theories refuted and replaced by new ones and why does the meaning of theoretical concepts change over time? Can philosophical theories about science be justified by historical facts? Can philosophical perspectives guide our study of 


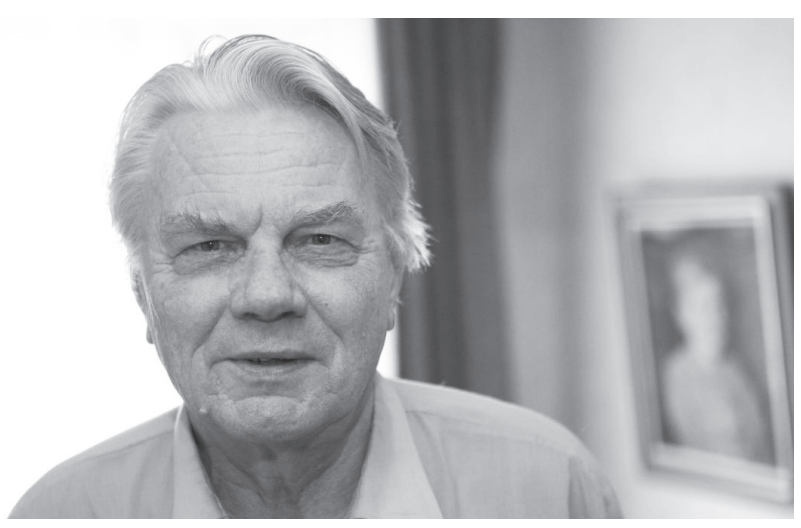

Rein Vihalemm.

Photo by Ove Maidla.

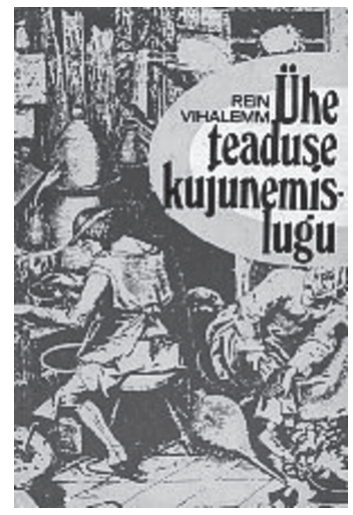

Original cover of the book in Estonian (1981).

the history of science? What is science after all? What constitutes the difference between chemistry and alchemy?

Rein Vihalemm, a graduate of physical chemistry from the Tartu State University in 1963, pursued his doctoral studies in philosophy, and in 1969 defended his $\mathrm{PhD}$ dissertation Стадии развития учения о химическом сродстве с точки зрения основных ступеней познания ('Stages of development of the study of chemical affinity from the perspective of main levels of cognition') at the Institute of Philosophy, Academy of Sciences of the USSR, Moscow. By then, he had published several articles on the epistemology of science. After obtaining the PhD degree, he continued lecturing at the Department of Philosophy, Tartu State University and focused in his research on the history and philosophy of science, primarily on the example of chemistry. In 1992, he became a Professor in Philosophy of Science at the University of Tartu. His main contributions to the philosophy of science are the theoretical concept of $\varphi$-science, an account of chemistry as a science with dual nature, a $\varphi$-science and a non- $\varphi$-science, and more recently practical realism, an empirically informed theoretical account of science. Altogether, Vihalemm authored over 130 academic publications, including eight monographs and collections of articles, he supervised many graduate students and inspired generations of intellectuals with his lectures and seminars.

The English translation of the book is dedicated to Rein Vihalemm's 80th birth anniversary. We hope that it will be a good supplement, and perhaps for those not yet familiar with Vihalemm's work, a good introduction to his other publications in English. 
The original references included in the book were mostly in Russian and are included in Bibliography. However, as conventions of academic citing have become considerably stricter since the book was written, the editors have had to identify numerous quotes from original sources. References to those original sources have been added to the list of bibliography alongside the references given in the book's original Estonian version. Wherever possible, we have used the original English text in quotes which may date back to the 17th century. In other cases, the translations are from the Estonian text and checked against originals in other languages (German, French, Latin). Needless to say, identification of the original works in the Internet Archive, BnF Gallica and other online sources could have hardly been possible before our current digital era.

The illustrations, too, have been updated and do not always exactly follow those in the original book. Again, largely owing to the digital nature of the materials and free online access to them, we have managed to include high-quality versions of several illustrations. Many of the portraits of philosophers and scientists had to be replaced with slightly different versions (often those available in Wikimedia Commons). Some historical drawings have been recovered (sometimes in fuller versions) from the copies in the Internet Archive or other sources, some have been recreated by our own designer.

Translation and publication of the book would not have been possible without the contribution and support of many people and institutions. First of all, we would like to extend our sincere gratitude to Rein Vihalemm's family. The publisher of the book in Estonian in 1981, Publishing Company "Valgus", also deserves our thanks. The Institute of Philosophy and Semiotics and the Faculty of Humanities and Arts of the University of Tartu have provided financial support to the project, and we are also indebted to the Estonian Research Council (grants no. 372 and 462). We wish to thank the Estonian Association of History and Philosophy of Science, its president Dr Peeter Müürsepp, and Kait Tamm and Piret Frey from the editorial team of the journal Acta Baltica Historiae et Philosophiae Scientarum. We owe thanks to our colleague Riin Kôiv and designer Maarja Roosi for their work with the illustrations. Last but not least, we are most grateful to the translators Ain Rada, Kait Tamm and Meelis Leesik.

Endla Lóhkivi and Ave Mets, Guest editors of the special edition

2 August 2019,

Tartu 
